\title{
Compare of three ways of synthesis of simple Schiff base
}

\section{Zhaoqi Yang*, Pinhua Sun}

Institute of New Drug Research, Jinan University College of Pharmacy, Guangzhou 516032, China e-mail: pharmacydoctor@163.com

* Author to whom correspondence should be addressed

Received: 6 July 2006 / Accepted: 3 August 2006 / Published: 1 December 2006

Keywords: Synthesis, Schiff base, Compare

\begin{abstract}
In this paper we propose the synthesis of $(E)$-4-methyl-N-(3,4,5-trimethoxybenzylidene) benzenamine in different ways and compare of the way of synthesize it. As a result, microwave irradiation is the simple way to synthesis this Schiff base.
\end{abstract}

\section{Introduction}

Schiff bases are typically formed by the condensation of a primary amine and an aldehyde. Schiff bases are important intermediates for the synthesis of various bioactive compounds. Furthermore, they are reported to show a variety of biological activities including antibacterial, antifungal, anti cancer and herbicidal activities [1-5]. On the other hand, they are fundamental material for synthesis of various Schiff base ligands which used as chiral auxiliaries in asymmetric synthesis. Metal complex Schiff bases have also been used in oxidation reactions [6].

In view of these facts we can clear about that Schiff base are important not only in medical chemistry, but also in organic synthetic chemistry. Schiff base perhaps are synthesized in various method. In this paper, we will research which the simple way to synthesize Schiff base via compare of three primary methods. For the sake of convenience to compare the result, we choose the simple material $(3,4,5-$ trimethoxybenzaldehyde and p-toluidine) to synthesize simple Schiff base.<smiles>COc1cc(C=O)cc(OC)c1OC</smiles>

\section{Scheme.1 synthesis of Schiff base}

\section{Experimental}

Melting points were uncorrected and were measured with micro-melting point apparatus XT-4. IR spectra (KBr) were obtained on a Thermo Nicolet Nexus 470 FT-IR spectrometer. ${ }^{1} \mathrm{H}$ NMR spectra were determined on a Varian Mecurry 300 spectrometer using $\mathrm{CDCl}_{3}$ as solvent and tetramethylsilane (TMS) as internal reference. Microwave irradiation was carried out with commercial LG domestic microwave oven $(1000 \mathrm{~W})$. All reagents were commercially available.

General procedure for the preparation of Schiff base ((E)-4-methyl-N- (3,4,5trimethoxybenzylidene)benzenamine)

\section{Way 1:}

A mixture of p-toluidine $(0.107 \mathrm{~g}, 1 \mathrm{mmol}), 3,4,5$-trimethoxybenzaldehyde $(0.196 \mathrm{~g}, 1 \mathrm{mmol})$, neutral alumina $(1 \mathrm{~g})$ and dichloromethane $(2 \mathrm{ml})$ in conical flask was introduced into the microwave oven and 
irradiated for $4 \mathrm{~min}$ (output power at 20\%). After cooling, the solid was recrystallized from ethyl acetate/petroleum ether to provide $(0.242 \mathrm{~g}, 85 \%)$ of the title compound as a white lamellar crystal.

\section{Way2:}

A solution of 3,4,5-trimethoxybenzaldehyde $(1 \mathrm{~g}, 5.09 \mathrm{mmol})$ in benzene $(10 \mathrm{~mL})$ was added dropwise in a solution of p-toluidine $(0.54 \mathrm{~g}, 5.09 \mathrm{mmol})$ in benzene $(5 \mathrm{~mL})$. The mixture was heated in reflux temperature, until no water appear(monitor with a Barrett distilling receiver). The solvent was removed in vacuo, and the residual was recrystallized from EtOAc to obtain the title compound $(1.05 \mathrm{~g}, 72 \%)$ as a white lamellar crystal.

\section{Way3:}

To a stirred solution of 3,4,5-trimethoxybenzaldehyde $(1 \mathrm{~g}, 5.09 \mathrm{mmol})$ and $7(0.54 \mathrm{~g}, 5.09 \mathrm{mmol})$ in $10 \mathrm{ml}$ $\mathrm{DCM}$, anhydrous $\mathrm{MgSO}_{4}$ was added. The reaction mixture was stirred 2 hours at room temperature. The resulting mixture was filtered through a sintered glass funnel with the aid of two $2 \mathrm{ml}$ portions of DCM, and then the filtrate was concentrated under reduced pressure by rotary evaporation at room temperature to afford yellow oil. The residual was dissolved in ethanol heated in an $80^{\circ} \mathrm{C}$ water bath while hot water was added with stirring. The resulting solution was allowed to cool to room temperature and then was cooled in an ice-water bath for $2 \mathrm{hr}$. Filtration provide the title compound (1.09 g, 75\%) as white lamellar crystal.

\section{Results and Discussion}

Compared with way 2 and way 3, way 1 has a great virtue. It is very suit for industrial manufacture which consumes the least time to finish the synthesis of Schiff base. Microwave irradiation synthesis is not only use the least time, but also has the greatest yield. From the table.1, we can know clearly that microwave irradiation is the simple way to synthesis this Schiff base. Microwave irradiation is becoming an increasingly popular method of heating which replaces the classical one because it proves to be a clean, cheap, and convenient method. Often, it affords higher yields and results in shorter reaction time. This method of heating has been extended to almost all areas of organic chemistry [7].

\section{Table.1 The compare of three way of synthesis of Schiff base}

\begin{tabular}{llll}
\hline Way & Reaction condition & Time & Yield \\
\hline 1 & microwave irradiation & $4 \min$ & $85 \%$ \\
2 & reflux & over $7 \mathrm{~h}$ & $72 \%$ \\
3 & rt stir & $4 \mathrm{~h}$ & $75 \%$ \\
\hline
\end{tabular}

Melting Point: $91-93^{\circ} \mathrm{C}$.

TLC: $\mathrm{R}_{\mathrm{f}}$ (silica; ethyl acetate: petroleum ether, 1:4) 0.40 .

$\operatorname{IR}\left(\mathrm{KBr} \mathrm{cm}^{-1}\right): 2954,2934,2835,1624,1558,1506,1460,1330,1127,1003$.

${ }^{1} \mathrm{H}-\mathrm{NMR}\left(300 \mathrm{MHz}, \mathrm{CDCl}_{3}\right): \delta=2.35\left(\mathrm{~s}, 3 \mathrm{H},-\mathrm{CH}_{3}\right) .3 .90\left(\mathrm{~s}, 9 \mathrm{H},-\left(\mathrm{OCH}_{3}\right) 3\right), 7.11(\mathrm{~s}, 6 \mathrm{H}, \mathrm{PhH}) .8 .31(\mathrm{~s}$, $1 \mathrm{H}, \mathrm{N}=\mathrm{CH})$.

\section{Acknowledgment}

The author is grateful to Professor Xianming Hu of the State Key Laboratory of Virology, College of Pharmacy, Wuhan University for experimental advice.

\section{References:}

1. Jarrahpour, A. A.; Jalbout, A. F.; Rezaei, S. and Trzaskowski, B. Molbank 2006, M455.

2. Taggi, A. E.; Hafez, A. M.; Wack, H.; Young, B.; Ferraris, D.; Lectka, T. J. Am. Chem. Soc. 2002, 124, 6626.

3. Jarrahpour, A. A.; Shekarriz, M. and Taslimi, A. Molecules 2004, 9, 29-38. 
4. Chohan, Z. H; Arif, M.; Shafiq, Z.; Yaqub, M. and Supuran, C.T. J. Enzyme. Inhib. Med. Chem., 2006, 21(1), 95-103.

5. Ren, S.; Wang, R.; Komatsu, K.; Bonaz-Krause, P.; Zyrianov, Y.; McKenna, C.E.; Csipke, C.; Tokes, Z.A. and Lien, E.J. J. Med. Chem., 2002, 45(2), 410-419.

6. Jarrahpour, A. A.; Rezaei, S. Molbank 2006, M456.

7. Corsaro, A.; Chiacchio, U.; Pistara, V. and Romeo, G. Curr.Org.Chem., 2004, 8(6), 511-538.

(C) 2006 MDPI. All rights reserved. 